Journal of Management and Bussines (JOMB)

Volume 1, Nomor 1, Juni 2019

p-ISSN : 2656-8918

e-ISSN: $2684-8317$

DOI : https://doi.org/10.31539/jomb.v1i1.622

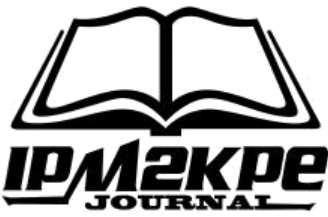

\title{
ANALISIS KINERJA KEUANGAN SEBELUM DAN SESUDAH RIGHT ISSUE
}

\author{
Rini Anisa ${ }^{1}$, Acep Samsudin ${ }^{2}$, Dicky Jhoansyah ${ }^{3}$ \\ Universitas Muhammadiyah Sukabumi ${ }^{1,2,3}$ \\ Email: Rinianissa85@gmail.com ${ }^{1}$
}

\begin{abstract}
ABSTRAK
Penelitian ini bertujuan untuk menganalisis perbedaaan kinerja keuangan perusahaan sebelum dan sesudah right issue pada perusahaan di BEI periode 2015-2016. Metode pengukuran kinerja keuangan menggunakan analisis wicoxon signed rank tes yang menggunakan beberapa rasio keuangan dari beberapa komponen. Pada laporan laba rugi dan neraca, yaitu Current Ratio (CR), Debt to equity ratio (DER), Total asset turnover (TATO), Return on equity (ROE). Pengambilan sampling pada penelitian ini menggunakan metode purposive sampling, sampel pada penelitian ini berjumlah 15 perusahaan di BEI yang melakukan right issue periode 2015-2016. Hasil penelitian ini menunjukan bahwa terdapat perbedaan signifikan pada rasio CR, DER dan TATO dua tahun sebelum dan dua tahun sesudah right issue sedangkan pada rasioROE tidak terdapat perbedaan signifikan dua tahun sebelum dan dua tahun sesudah right issue. hasil ini menunjukan bahwa kinerja keuangan perusahaan dua tahun sebelum dan dua tahun sesudah right issue lebih efisien dalam meningkatkan utang jangka pendek dan jangka panjang serta dalam memanfaatkan aktiva penjualan perusahaan meningkat.
\end{abstract}

Kata Kunci: Right Issue, Current Ratio, Analisis Kerja

\section{ABSTRACT}

This Research was meant to analyze the differences in the company's financial performance before and after the rights issue for companies on the IDX for the period 2015-2016. The financial performance measurement method uses the analysis of the wicoxon signed rank test which uses several financial ratios from several components. In the income statement and balance sheet, namely Current Ratio $(C R)$, Debt to equity ratio (DER), Total asset turnover (TATO), Return on equity (ROE). Sampling in this study using purposive sampling method, the sample in this study amounted to 15 companies on the IDX that carried out rights issues for the period 2015-2016. The results of this study indicate that there are significant differences in the ratio of $C R$, DER and TATO two years before and two years after the rights issue, while in the ROE ratio there are no significant differences two years before and two years after the rights issue. This result shows that the company's financial performance two years before and two years after the rights issue is more efficient in increasing short-term and long-term debt and in utilizing the company's sales assets to increase.

Keywords: Right Issue, Current Ratio, Work Analysis 


\section{PENDAHULUAN}

Maraknya bisnis dibidang yang sama membuat persaingan bisnis menjadi salah satu risiko besar yang harus dihadapi pelaku usaha. Perusahaan yang mulai berkembang membuat pemilik tak mampu lagi membiayai dana operasi perusahaan dan kinerja perusahaan, sehingga pemilik usaha memutuskan untuk mencari dana tambahan dari pihak luar seperti pasar modal. Sebagian besar para pelaku usaha yang mencatatkan perusahaanya dibursa efek Indonesia atau dikenal sebagai perusahaan go public artinya telah memutuskan untuk menjual sahamnya kepada publik dan sudah siap untuk dinilai oleh publik secara terbuka (Irham Fahmi 2014). Setelah tercatat di BEI perusahaan dapat menjual kepemilikan sahamnya kepada masyarakat, sehingga pemilik lama harus mau berbagi kepemilikannya dengan pemilik saham yang baru. Namun pemilik lama pada umumnya tidak akan semudah itu untuk melepaskan kepemilikannya, pemilik lama akan membuat kepemilikannya menjadi prioritas utama pada perusahaan meskipun sahamnya dibagi-bagi dengan pemilik saham yang baru.

Menurut Guido Giyak (2018) pemegang saham akan bereaksi segala informasi positif dan negative yang diterima sebelum melakukan pembelian atas saham perusahan. Dalam hal ini dapat diartikan dana right issue dapat memberikan informasi positif jika dana dilakukan untuk ekspansi usaha dan investasi digambarkan kinerja keuangan perusahaan akan mengalami peningkatan sedangkan informasi negative jika dana dilakukan untuk pembayaran hutang kinerja keuangan perusahaan akan mengalami penurunan.

Keputusan right issue dengan kinerja keuangan perusahaan memiliki hubungan dekat dengan berbagai tujuan perusahaan dalam mencari keterbatasan dana membuat para investor kurang yakin dengan dana tambahan yang diminta oleh perusahaan, maka dari itu diperlukan informasi laporan keuangan yang menjadikan tolak ukur perusahaan dalam mengembangkan dana investasinya dengan benar dan mampu memberikan keuntungan bagi investor.

Perusahaan di BEI merupakan perusahaan yang sudah terbuka serta dapat meraup dana tambahan dengan jumlah yang cukup besar salah satunya melalui right issue, pada tahun 2013-2016 tercatat perusahaan melakukan right issue mengalami peningkatan. Tahun 2013 jumlah perusahaan yang melakukan Right Issue berjumlah 19, tahun 2014 berjumlah 25, tahun 2015 berjumlah 20 dan tahun 2016 berjumlah 32 
perusahaan. Dari data ini dapat disimpulkan setiap tahunya perusahaan yang melakukan right issue mengalami peningkatan dengan tujuan dan mendapatkan jumlah dana yang dibutuhkan perusahaan. Adanya perusahaan yang melakukan right issue menunjukan pasar modal menjadi salah satu opsi bagi perusahaan yang membutuhkan dana tambahan. Tentunya kebutuhan informasi bagi pemegang saham dilihat dari laporan keuangan perusahaan. Dengan demikian dibutuhkan suatu penilaian terhadap kinerja perusahaan, karena hal tersebut dapat mempengaruhi kepercayaan diri perusahaan sekaligus pemahaman pemegang saham dalam pengambilan keputusan.

Pemegang saham dan pihak-pihak yang berkepentingan perlu informasi perusahaan yang melakukan right issue dengan melihat kinerja perusahaan yang kemungkinan dana tambahan right issue digunakan secara benar atau salahnya dalam pengambilan keputusan penambahan dana right issuetersebut.Laporan keuangan merupakan informasi bagi para pemegang saham dalam penilaian aspek kinerja keuangan perusahaan dalam menjalankan aktivitas bisnisnya. Berbeda atau tidaknya kinerja keuangan perusahaan sebelum dan sesudah melakukan right issue dapat di ukur menggunakan analisis rasio keuangan.

Tema yang diusulkan dalam penelitian ini adalah analisi kinerja keuangan sebelum dan sesudah right issue (Studi keuangan pada perusahaan di BEI periode 20152016). Tujuan penelitian ini untuk mengetahui perbedaan kinerja keuangan perusahaan di BEIdua tahun sebelum dan dua tahun sesudah right issueyang ditinjau dari rasio current ratio, debt to equityratio, total asset turnover dan return on equity.

\section{KAJIAN TEORI}

\section{Pasar Modal}

Pasar modal adalah tempat dimana berbagai pihak khususnya perusahaan menjual saham (stock) dan obligasi (bond) dengan tujuan dari hasil penjualan tersebut nantinya akan dipergunakan sebagai tambahan dana atau memperkuat modal perusahaan. Menurut Irham Fahmi (2014), instrument pasar modal menurut Samsul (2006) dibagi menjadi 5 yaitu : 1. Saham, 2. Obligasi, 3. Bukti right issue, 4. Bukti Waran, 5. Derivative 


\section{Right issue}

Menurut Irham Fahmi (2014) right issue adalah pemberian hak pemegang saham lama untuk memesan terlebih dahulu saham emiten yang akan dijual dengan harga nominal tertentu. Biasanya keputusan right issue tersebut dilakukan oleh emiten untuk penambahan keterbatasan modal perusahaan.

\section{Right issue dan kepentingan investor}

Menurut Fakhrudin dan Hendy (2008) Aksi kebijakan right issue banyak ditanggapi oleh para investor. para investor perlu mempertimbangkan pengeluaran saham emiten lewat right issue apakah harus membeli atau tidak. Investor harus melihat minimal pada hal-hal berikut : 1) latar belakang dilakukannya right issue; 2) tujuan right issue; 3) rencana pengguna right issue; 4) harga pelaksanaan dan rasio right issue.

\section{Hubungan right issue dengan kinerja keuangan}

Ada hubungan dekat antara kebijakan right issue dengan kinerja keuangan suatu perusahaan. secraa teori keputusan right issue disebabkan oleh beberapa faktor, seperti kebutuhan dana, dan peursahaan merasa dana yang dimiliki saat ini tidak lagi tercukupi. Selanjutnya keputusan right issue juga dilandasi oleh faktor tidak ingin mengambil atau menambah lagi pinjaman pada pihak perbankan, dan juga sumber bentuk pinjaman lainnya seperti penerbitan obligasi. (Irham Fahmi 2014).

\section{Analisis Rasio Keuangan}

Menurut Murhadi (2013) mengenai Analisis rasio digunakan dengan cara membandingkan suatu angka tertentu pada suatu akun terhadap angka dari akun lainnya. Analisis rasio sering digunakan oleh manajer, analisis kredit dan analisis saham. Analisis rsio bermanfaat karena membadingkan suatu angka secar relatif sehingga bisa menghindari kesalahan penafsiran pada angka mutlak yang ada didalam laporan keuangan.

Analisis rasio keuangan dilakukan oleh perusahaan agat perusahaan mengetahui kinerjanya dengan membandingkan komponen-komponen yang ada dalam laporan keuangan sehingga terlihat apakah nilai sudah cukup tinggi bila dibadingkan dengan komponen lainnya. Karena niali suatu komponen dalam laporan keuangan 
yangtinggi belum tentu cukup baik apabila dibandingkan dengan komponen lainnya dalam laporan keuangan.

\section{METODE PENELITIAN}

Dalam penelitian ini dilakukan analisis perbedaan data kuantitatif yang berbentuk komparatif berupa angka-angka rasio yang diperoleh dan diuraikan sesuai dengan masalah yang akan diteliti menggunakan data historis yang berasal dari laporan keuangan perusahaan yang diperoleh dari bursa efek Indonesia tahun 2013 sampai tahun 2017.

Penilaian kinerja keuangan perusahaan berdasarkan pada rasio-rasio keuangan yang telah diolah dari laporan keuangan yang telah diaudit dibursa efek Indonesia. Rasio-rasio keuangan meliputi:

Current ratio dalam penelitian ini untuk mengetahui perbadingan perusahaan dalam utang jangka pendek dua tahun sebelum dan dua tahun sesudah right issue pada perusahaan di BEI yang melakukan right issue periode 2014-2015. Dapat diukur menggunakan rumus sebagai berikut :

$$
\mathrm{CR}=\frac{\text { Aktiva Lancar (current asset) }}{\text { Utang Lancar (current liabilities) }}
$$

Debt to euity ratio dalam penelitian ini untuk mengetahui perbandingan seluruh utang perusahaan dengan ekuitas dua tahun sebelum dan dua tahun sesudah right issue pada perusahaan di BEI yang melakukan right issue periode 2014-2015. Dengan rumus sebagai berikut :

$$
\mathrm{DER}=\frac{\text { Total Utang }(\text { debt })}{\text { Ekuitas (equity) }}
$$

Total asset turnover dalam penelitian ini untuk mengetahui perbandingan jumlah penjualan yang diperoleh dari tiap aktiva perusahaan dua tahun sebelum dan dua tahun sesudah right issue pada perusahaan di BEI yang melakukan right issue periode 2015-2016, dengan rumus sebagai berikut :

$$
\text { TATO }=\frac{\text { Penjualan }}{\text { Total Aktiva }}
$$


Return on euity dalam penelitian ini untuk mengetahui perbandingan laba bersih sesudah pajak dengan modal sendiri dilihat dari dua tahun sebelum dan dua tahun sesudah right issue pada perushaaan di BEI yang melakukan right issue periode 20152016. Dengan rumus sebagai berikut :

$$
\mathrm{ROE}=\frac{\text { Earning After Interest and Tax }}{\text { Equity }}
$$

Populasi pada penelitian ini adalah semua perusahaan yang terdafatar di bursa efek Indonesia yang melakukan right issue periode 2015 - 2016. Populasi tersebut sebanyak 53 perusahaan.Sampel merupakan bagian dari jumlah dan karakteristik dari populasi (Sugiyono,2013). Teknik sampling pada penelitian ini adalah non probability sampling yang menggunakan metode purposive sampling untuk mendapatkan perusahaan yang memenuhi syarat kriteria penelitian.

Tabel 1. Kriteria Penentuan Sampel

\begin{tabular}{cc}
\hline Kriteria & Jumlah \\
\hline perusahaan yang melakukan right issue pada periode 2015-2016 & 53 \\
perusahaann lembaga keuangan dan perbankan & $(28)$ \\
data laporan keuangan tidak lengkap data yang akan diteliti & $(8)$ \\
perusahaan yang melakukan right issue lebih dari satu kali & $(2)$ \\
\hline Data yang akan diteliti & 15 \\
\hline
\end{tabular}

\section{Jenis dan Sumber Data}

Data yang digunakan dalam penelitian ini adalah data skunder dalam bentuk laporan keuangan tahunan yang telah diaudit tahun yang terakhir pada 31 Desember 2013 sampai dengan 31 Desember 2017 yang diperoleh dari bursa efek Indonesia melalui situs internet http://www.idx.co.idSumber data perusahaan yang melakukan right issue diperoleh dari www.Sahamok, dan situs PT Kusindo Sentral Efek Indonesia. Sumber data lainnya yaitu studi kepustakaan seperti buku, tulisan ilmiah dan sumber data lainnya.

\section{Langkah-langkah Analisis Data}

Dalam penelitian ini adalah uji normalitas,uji statistik deskriptif dan pengujian hipotesis. Uji normalitas untuk mengetahui apakah data yang digunkaan berdistribusi normal atau tidak dengan menggunakan statistik non parametik dengan uji satu sampel Klomogrov-smirnov. 
Selanjutnya uji statistik deskriptif yang memberikan gambaran atau deskripsi suatu data yang dilihat dari nilai rata-rata (mean), standar deviasi, maksimum dan minimum. Kemudian uji pengujian hipotesis melalui uji beda dilakukan dengan dua alternativ metode yaitu uji statistik parametik atau uji statistik non-parametik. Penentuan pemakaian metode uji dilakukan berdasarkan hasil uji normalitas (kolomogrov-smirnov test). Jika hasil uji menunjukan data berdistribusi normal maka digunakan uji statistik paramerik yang menggunakan teknik paired sample t test sedangkan jika data tidak berdistribusi normal digunakan uji statistik non parametrik menggunakan teknik Wilcoxon signed ranks test.

\section{HASIL PENELITIAN}

Berikut diuraikan pada tabel 1 daftar sampel perusahaan yang sudah memenuhi kriteria penentuan sampel. Kinerja keuangan dapat diukur melalaui rasio keuangan yang ada dilaporan keuanagn perusahaan. rasio keuangan ini adalah current ratio,debt to equity ratio,total asset turnoverdan returnon equity. Penelitian menggunakan 15 perusahaan yang menjadi sampel penelitian ini.

Tabel 2. Daftar Sampel Perusahaan

\begin{tabular}{ccc}
\hline No & Kode & Nama Perusahaan \\
\hline 1 & TOTO & Surya Toto Indonesia Tbk \\
2 & WSKT & Waskita Karya (persero) Tbk \\
3 & CENT & Centratama Telekomunikasi Indonesia Tbk \\
4 & ADHI & Adhi Karya (persero) Tbk \\
5 & ANTM & Aneka Tambang Tbk \\
6 & HMSP & Hanjaya Mandala Sampoerna Tbk \\
7 & MAIN & Malindo Feedmil Tbk \\
8 & SIPD & Catur Sentosa Adiprana Tbk \\
9 & CSAP & Graha Layar Prima Tbk \\
10 & BLTZ & Astra Agro Lestari Tbk \\
11 & AALI & Berlina Tbk \\
12 & BRNA & Sejahteraraya Anugrahjaya Tbk \\
13 & SRAJ & Karakatau Steel Tbk \\
14 & KRAS & Alam Karya Unggul Tbk \\
15 & AKKU & \\
\hline
\end{tabular}




\section{Sumber dari Sahamok dan Ksei}

Untuk melakukan teknik analisi, peneliti menggunakan bantuan perangkat lunak SPSS 24.

Tabel 3. Uji Normalitas

\begin{tabular}{clccc}
\hline Variabel & Periode & P Value & Sig (2-tailed) & Keterangan \\
\hline Current Ratio & Sebelum & 0,084 & 0,05 & Normal \\
& Sesudah & 0,000 & 0,05 & Tidak Normal \\
Debt toequity & Sebelum & 0,000 & 0,05 & Tidak Normal \\
ratio & Sesudah & 0,004 & 0,05 & Tidak Normal \\
Total Asset & Sebelum & 0,002 & 0,05 & Tidak Normal \\
turnover & Sesudah & 0,005 & 0,05 & Tidak Normal \\
Return on Equity & Sebelum & 0,000 & 0,05 & Tidak Normal \\
& Sesudah & 0,000 & 0,05 & Tidak Normal \\
\hline
\end{tabular}

Dapat dilihat tabel 3, menunjukan bahwa nilai $\mathrm{p}$ Value current ratio sebelum sebesar 0,084 lebih besar dari taraf signifikan $(0,084>0,05)$ sehingga Ho ditolak, ini berarti current ratio sebelum berdistribusi normal. Nilai $p$ value current ratio sesudah sebesar 0,000 lebih kecil dari taraf signifikan $(0,000<0,05)$ sehingga Ho diterima ini berarti current ratio sesudah berdistribusi tidak normal.

Nilai $P$ value debt equity ratio sebelum sebesar 0,000 lebih kecil dari tingkat signifikan $(0,000<0,05)$ sehingga Ho diterima, ini berarti debt equity ratio sebelum berdistribusi tidak normal. Nilai $p$ value debt equity ratio sesudah sebesar 0,004 yang lebih kecil dari taraf signifikan $(0,004<0,05)$ sehingga Ho diterima ini berarti debt equity ratio sesudah berdistribusi tidak normal.

Nilai $p$ value total asset turnover sebelum sebesar 0,002 yang lebih kecil dari tingkat siginifikansi $(0,002<0,05)$ sehingga Ho diterima, ini berarti total asset turnover sebelum berdistribusi tidak normal. Nilai $p$ value total asset turnover sesudah sebesar 0,005 yang lebih kecil dari taraf signifikansi $(0,005<0,05)$ sehingga Ho diterima in berarti total asset turnover sesudah berdistribusi tidak normal.

Nilai $p$ value return on equity sebelum sebesar 0,000 yang lebih kecil dari tingkat signifikansi $(0,000<0,05)$ sehingga Ho diterima, ini berarti return on equity sebelum berdistribusi tidak normal. Nilai p value return on equity sesudah sebesar 0,000 yang lebih kecil dari taraf signifikansi $(0,000<0,05)$ sehingg Ho diterima ini berarti return on equity sesudah berdistribusi tidak normal.

Berdasarkan uji klomogrov- smirnov semua data variabel tidak memenuhi syarat berdistribusi tidak normal karena nilai $p$ value kurang dari taraf signifikansi $(\alpha=$ 
0,05) karena data berdistribusi tidak normal maka menggunakan metode penguji hipotesis teknik analisis non parametik Wilcoxon signed rank test.

Tabel 4. Uji Statistic Deskriptif

\begin{tabular}{cccc}
\hline No & Variabel & Rata-rata sebelum & Rata-rata sesudah \\
\hline 1. & Current ratio & 1,3770 & 1,9937 \\
2. & Debt to equity ratio & 2,2440 & 1,0359 \\
3. & Total asset turnover & 0,8393 & 0,7404 \\
4. & Return on equity & $-1,9341$ & 365,7271 \\
\hline
\end{tabular}

Tabel 5. Uji Hipotesis

\begin{tabular}{ccccc}
\hline Hipotesis & Variabel & Rata-rata & Nilai signifikan & Keterangan \\
\hline \multirow{2}{*}{ H1 } & CR sebelum & 1,3770 & 0,002 & Signifikan \\
& CR sesudah & 1,9937 & & \multirow{2}{*}{ Signifikan } \\
H2 & DER sebelum & 2,2440 & 0,000 & \multirow{2}{*}{ Signifikan } \\
& DER sesudah & 1,0359 & & \multirow{2}{*}{0,049} \\
H3 & TATO sebelum & 0,8393 & & Tidak signifikan \\
& TATO sesudah & 0,7404 & \multirow{2}{*}{0,734} & \\
\hline
\end{tabular}

Berdasarkan tabel 5 dengan menggunakan pengujianWilcoxon signed rank testdan tingkat keyakinan 0,05, sebagai berikut :

Uji H1 Current ratiomenunjukan bahwa Z sebesar -3,137. Nilai sig (2tailed)hasil 0,002 lebih kecil dari 0,05 $(0,002<0,05)$ sehingga dapat disimpulkan bahwa Ho ditolak dan $\mathrm{H} 1$ diterima. Hal ini berarti current ratioterdapat perbedaaan signifikan dua tahun sebelum dan dua tahun sesudah right issue.

Uji H2 Debt to equity ratio menunjukan bahwa Z sebesar -3,630. Nilai sig (2tailed) menunjukan hasil 0,000 lebih kecil dari 0,05 $(0,000<0,05)$ sehingga dapat disimpulkan bahwa Ho ditolak dan $\mathrm{H} 2$ diterima. Hal ini berarti debt to equity ratioterdapat perbedaaan signifikan dua tahun sebelum dan dua tahun sesudah right issue.

Uji H3 Total asset turnovermenunjukan bahwa Z sebesar -1,964. Nilai sig (2tailed) menunjukan hasil 0,049 lebih kecil dari $0,05(0,049<0,05)$ sehingga dapat disimpulkan bahwa Ho ditolak dan $\mathrm{H} 3$ diterima. Hal ini berarti total asset turnoverterdapat perbedaaan signifikan dua tahun sebelum dan dua tahun sesudah right issue.

Uji H4 Return on equitymenunjukan nilai Z sebesar -0,339. Nilai sig (2-tailed) menunjukan hasil 0,734 lebih besar dari 0,05 $(0,734>0,05)$ sehingga dapat disimpulkan 
bahwa Ho diterima dan $\mathrm{H} 4$ ditolak. Hal ini berarti bahwa return on equity tidak berbeda siginifikan dua tahun sebelum dan dua tahun sesudah right issue.

\section{PEMBAHASAN}

\section{Current ratio Terdapat perbedaan sebelum dan sesudah right issue}

Hasil penelitian ini sama dengan penelitian (Siscania, 2017), dimana CR terdapat perbedaan sebelum dan sesudah right issue. Hal ini dapat dibuktikan dari hasil nilai probabilitas lebih kecil dari nilai signifikan $(0,002<0,05)$, sehingga dapat disimpulkan bahwa Ho ditolak dan H1 diterima. Hasil ini mengidentifikasikan bahwa dana right issue dimanfaatkan untuk memenuhi kewajiban lancar perusahaan. kewajiban lancar terdiri dari utang usaha, wesel tagih jangka pendek, utang lancar jangka panjang, pajak dan gaji yang harus dibayar.

\section{Debt to equity ratio Terdapat perbedaan sebelum dan sesudah right issue}

Hasil penelitian ini menunjukan DER terdapat perbedaan karena nilai probabilitas lebih kecil dari niali signifikan $(0,000<0,05)$ sehingga dapat disimpulkan bahwa Ho ditolak dan $\mathrm{H} 2$ diterima. Hal ini mengidentifikasi bahwa dana right issuedigunakan sebagai modal perusahaan dan untuk kepentingan pemabayaran hutang, investasi jangka panjang, pengembangan usaha untuk meningkatkan penjualan.

\section{Total asset turnover Terdapat perbedaan sebelum dan sesudah right issue}

Hasil penelitian ini sama dengan penelitian (Guido,2018), dimana TATO terdapat perbedaan sebelum dan sesudah right issue. Hal ini dapat dibuktikan dari hasil nilai probabilitas lebih kecil dari niali signifikan $(0,049<0,05)$ sehingga dapat disimpulkan bahwa Ho ditolak dan H3 diterima. Hasil ini mengidentifikasikan bahwa dana right issue meningkatkan rata-rata perputaran total aktiva dan mengalami perbedaan secara signifikan sebelum dan sesudah right issue.

\section{SIMPULAN}

Righit issue yang dilakukan dari hasil penelitian ini menunjukan beberpa rasio kinerja keuangan (CR, DER, TATO, dan ROE) pada dua tahun sebelum dan dua tahun sesudah right issue, hanya tiga rasio saja yaitu CR, DER dan TATO saja yang berbeda 
secara signifikan pada sebelum dan sesudah right issue. karena right issue sangat cukup di butuhkan oleh perusahaan dalam meningkatkan kinerja perusahaan yang mengalami kekurangan modal.

\section{DAFTAR PUSTAKA}

Irham, Fahmi. (2014). Manajemen Keuangan Perusahaan dan Pasar Modal. Jakarta: Mitra Wacana Media.

Fakhruddin dan Hendy. (2008). Go Public Strategi Pendanaan dan Peningkatan Nilai Perusahaan. Jakarta: PT Elex Media Komputindo.

Murhadi, W.(2013). Analisis Laporan Keuangan Proyeksi dan Valuasi Saham. Jakarta: Salemba Empat.

Guido, G. R. (2018). Analisis Kinerja Keuangan Perusahaan Sebelum dan Sesudah Right Issue di BEI. E-jurnal Manajemen Unud, 7 (3)

Samsul, Mohammad. (2006). Pasar Modal dan Manajemen Portofolio. Surabaya: Erlangga

Siscania, Y. P. (2017). Analisis Profitabilitas dan Likuiditas Sebelum dan Sesudah Right Issue. Jurnal Manajemen Bisnis Indonesia, 4 (3).

Sugiyono. (2013). Metode Penelitian Bisnis. Bandung: Alfabeta.

BEI (Bursa Efek Indonesia). (2019). https://www.idx.co.id/

Sahamok. (2015). https://www.sahamok.com/emiten/hmetd-right-issue/

Ksei. (PT Kusindo Central Efek Indonesia). (2016). http://www.ksei.co.id/publications/corporate-actio-schedules/rights-distribution 